Kebijakan: Jurnal Ilmu Administrasi

Volume 12, Nomor 2, Juni 2021

E-ISSN: 2656-2820

P-ISSN 1829-5762

\title{
BUDAYA 5S SEBAGAI WUJUD REFORMASI BIROKRASI DALAM PELAYANAN PUBLIK DI SMK SMAK PADANG
}

\author{
Ismaya Indri Astuti
}

\author{
SMK SMAK Padang, BPSDMI - Kementerian Perindustrian \\ ${ }^{1}$ Padang, Sumatera Barat, Indonesia \\ ismayaindri@kemenperin.go.id
}

Visi reformasi birokrasi akan menjadi nyata jika tata kelola birokrasi yang baik dimulai dari budaya melayani tanpa pamrih. Aparatur layanan publik sudah saatnya berbenah untuk memberikan layanan kepada masyarakat dengan sepenuh hati yang tercermin dari kesungguhan aparatur dalam melayani. Saat ini Pemerintah pemerintah sedang gencar melakukan reformasi birokrasi baik di instansi pusat maupun di daerah. Sejalan dengan Road Map Kementerian Perindustrian Republik Indonesia, SMK SMAK Padang secara konsisten memaksimalkan pelayanan dengan mendahulukan kepentingan masyarakat. Untuk mewujudkannya harus ada perubahan karakter, salah satu upaya SMK SMAK Padang dalam memaksimalkan pelayanan publik ialah dengan membudayakan 5S (Senyum, Sapa, Salam, Sopan, Santun). Budaya 5S yang dilakukan di SMK SMAK Padang tidak muncul begitu saja, tetapi diupayakan melalui suatu proses yang terkendali dengan melibatkan semua sumber daya manusia dalam seperangkat sistem. SMK SMAK Padang menjadi tempat untuk menyoalisasikan nilai-nilai budaya yang tidak hanya terbatas hanya nilai-nilai keilmuan saja, namun semua nilai-nilai kehidupan yang memungkinkan bisa mewujudkan manusia yang berbudi dan berbudaya. Sebagai salah satu instansi dengan predikat Zona Integritas WBK WBBM lekat dengan pelayanan yang optimal dan maksimal, maka keberhasilan dari suatu pelayanan dapat diukur melalui kepuasan yang dirasakan oleh masyarakat.

Kata kunci: Reformasi Birokrasi, Budaya 5s, Pelayanan Publik

\begin{abstract}
The vision of Bureautic Reform will become real if the Bureautic Good Governance starts from the habit of service itself. The servants of public service should improve themselves to provide services for the community wholeheartedly which is reflected in the seriousness of the servants in a good serving. Nowdays, the government is intensively carrying out bureaucratic reforms both in central and regional agencies. In line with the Road Map of the Ministry of Industry of the Republic of Indonesia, Padang Chemical Analyst Vocational School consistently maximizes services by prioritizing the interests of the community. To make it happen there must be a change in character, one of the effort of Padang Chemical Analyst Vocational School in maximizing public services through by $5 S$ Culture (Smile, Regrads, Greetings, Polite, Courteous). The 5S Culture that was carried out at Padang Chemical Analyst Vocational School did not appear itself, but is pursued through a controlled process involving by all human resources in this system. Padang Chemical Analyst Vocational School is a place to promote cultural values that are not only limited to scientific values but all possible values of life that can be becoming righteous human and cultured people. As one of the government agencies with the title of the Zona Integritas WBK WBBM is closely related to optimal and maximum service, the success of service can be measured through the satisfaction felt by the community.
\end{abstract}

Keywords: Bureautic Reform, 5S Culture, Public Service

\section{PENDAHULUAN}

Saat ini pemerintah sedang gencar melakukan reformasi birokrasi baik di instansi pusat maupun di daerah. Birokrasi kini mengalami perkembangan yang tidak lagi tergambar sebagai sesuatu yang meribetkan dan membutuhkan waktu lama. Beberapa tahun lalu, sebagian besar birokrasi di Indonesia hampir rata penuh sengkarut dan sangat ruwet dalam pelayanan kepada masyarakat. Gould memaparkan 


\section{Kebijakan: Jurnal Ilmu Administrasi}

Volume 12, Nomor 2, Juni 2021

E-ISSN: 2656-2820

P-ISSN 1829-5762

bahwa birokrasi adalah makhluk yang mengerikan, mempunyai alat-alat penangkap yang senentiasa memperluas genggamannya, dan sekaligus merupakan lembaga yang paling korup dan merusak dalam masyarakat (Lubis dan Scoot, 1987:73). Sudah menjadi hal biasa ditemui permasalahan seperti: birokrat bermental priyayi yang enggan melayani, praktik KKN yang dianggap biasa, sarana pelayanan yang buruk, hingga kesulitan mengurus perizinan, adalah gambaran negatif betapa reformasi birokrasi di Indonesia sangat buruk sekali saat itu.

Birokrasi erat dengan cerminan pemerintah yang merupakan sumber daya manusia yang menjalankan roda pemerintahan saat itu, dimulai dari pegawai biasa sampai dengan kalangan pejabat yang memiliki kewenangan. Menurut Michan dalam Harliandja Denny (1999:58), memaparkan bawah birokrasi merupakan sekelompok orang yang menjalankan tugas-tugas mereka menurut aturan-aturan dan prosedur Negara yang mengayomi warganya yang telah ditetapkan berdasarkan ketentuanketentuan jabatan.

Dulu keburukan birokrasi secara umum tidak dapat dielakkan juga tercermin dalam birokrasi pendidikan. Birokrasi pendidikan sebagai bagian yang tidak terpisahkan dari birokrasi pemerintahan secara umum juga terasuki keserakahan birokrasi. Keberadaan birokasi pendidikan seperti itu lebih banyak merusak dari pada membangun pendidikan. Keberadaan kantor-kantor pendidikan dari tingkat kabupaten hingga ke pusat lebih banyak menggerogoti daripada menyumbang perkembangan pendidikan (Rohman, 2012: 126).

Tata kelola birokrasi yang baik sudah seharusnya dimulai dari budaya melayani tanpa pamrih, dengan begitu visi reformasi birokrasi menjadi nyata. Visi dari reformasi birokrasi ialah terwujudnya pemerintahan yang amanah atau terwujudnya tata kepemerintahan yang baik (Sedarmayanti, 2009). Aparatur layanan publik sudah saatnya berbenah untuk memberikan layanan kepada masyarakat dengan sepenuh hati yang tercermin dari kesungguhan aparatur dalam melayani. Keberhasilan dari suatu pelayanan dapat diukur melalui kepuasan yang dirasakan oleh pelanggan. Untuk mewujudkannya harus ada perubahan karakter, pola pikir dan reformasi pola kerja yang efektif dan efsien (Joko Widodo, 2016).

Namun, beda halnya dengan birokrasi pendidikan di bawah naungan Kementerian Perindustrian. SMK SMAK Padang merupakan salah satu unit pelaksana teknis dibidang pendidikan kejuruan formal di lingkungan Kementerian Perindustrian yang berada dibawah dan bertanggungjawab kepada Kepala Badan Pengembangan Sumber Daya Manusia Industri. Pada tahun 2018, SMK SMAK Padang meraih apresiasi Zona Integritas 2018 dengan predikat Wilayah Bebas dari Korupsi (WBK) yang diselenggarakan oleh Kementerian Pendayagunaan Aparatur Negara dan Reformasi Birokrasi (PAN-RB).

Birokrasi dengan berpredikat Zona Integritas lekat dengan pelayanan yang optimal. Sebagai bentuk wujud Zona Integritas, SMK SMAK Padang telah berupaya untuk kampanye stop gratifikasi terhadap siswa, orang tua siswa dan stakeholders lainnya; lalu berupaya untuk melakukan pengembangan inovasi di bidang paten hasil inobasi Analisis Terpadu; konsisten dalam menulis jurnal penelitian ber-ISSN, melaksanakan student and teacher exchange; menerapkan Sekolah Adiwiyata dan Sekolah Sehat; melaksanakan kurikulum Dual System dalam pembelajaran, serta pelayanan publik dengan menerapkan Budaya 5S (Senyum, Sapa, Salam, Sopan, Santun).

Seiring dengan perkembangan zaman, birokrasi dan pelayanan publik adalah dua hal yang tidak dapat dipisahkan. Penerapan pelayan publik yang berfokus pada masyarakat dapat berhasil apabila dari awal telah menyusun rencana dan menyelesaikan aktivitas pelayanan demi tercapaianya tujuan-tujuan pelayanan. Salah satu upaya SMK SMAK Padang dalam memaksimalkan pelayanan publik ialah dengan membudayakan 5S (Senyum, Sapa, Salam, Sopan, Santun) kepada masyarakat. Tidak hanya kepada masyarakat, seluruh warga sekolah meliputi Peserta Didik, Guru, Tenaga Kependidikan dan seluruh Staf wajib membiasakan diri untuk menerapkan Budaya 5S. Dengan membiasakan diri 
menerapkan Budaya 5S di lingkungan sekolah, diharapkan mampu meningkatkan rasa nyaman bagi seluruh warga SMK SMAK Padang, para tamu ataupun masyarakat yang berkunjung.

Sebagai salah satu instansi yang telah mendapat predikat Zona Integritas, SMK SMAK Padang secara konsisten memaksimalkan pelayanan dengan mendahulukan kepentingan masyarakat, mempermudah urusan masyarakat, mempersingkat waktu proses pelaksanaan urusan masyarakat dan memberikan kepuasan kepada masyarakat. Kualitas pelayanan yang memuaskan itu adalah dapat memuaskan kepada orang atau kelompok orang yang dilayani, maka pelaku dalam hal ini yaitu petugas harus dapat memenuhi empat persyaratan pokok meliputi: tingkah laku yang spontan, cara menyampaikan sesuatu yang berkaitan dengan apa yang seharusnya diterima oleh orang yang bersangkutan, waktu menyampaikan yang tepat, serta keramahtamahan. (Moenir, 2001:197).

Budaya 5 S yang telah dilakukan di SMK SMAK Padang tidak muncul begitu saja, tetapi harus diupayakan melalui suatu proses yang terkendali dengan melibatkan semua sumber daya manusia dalam seperangkat sistem, alat-alat serta teknik-teknik pendukung lainnya. Budaya $5 \mathrm{~S}$ merupakan landasan untuk merubah cara kerja lama menjadi cara kerja baru yang berorientasi untuk memenuhi kebutuhan dan memberi kepuasan pelayanan kepada masyarakat yaitu sesuai harapan pelayanan yang cepat, ramah, dan adil serta komunikatif.

\section{METODE}

Metode yang digunakan dalam penelitian ini adalah metode kualitatif-eksplanatori. Untuk mendapatkan narasumber yang tepat dan sesuai tujuan, Pengumpulan data dilakukan dengan meggunakan teknik wawancara, dokumentasi, studi pustaka dan observasi langsung terkait peningkatan kualitas pelayanan dalam rangka reformasi birokrasi di SMK SMAK Padang.

\section{PEMBAHASAN}

\section{Hasil Penelitian}

Pada hasil penelitian akan dipaparkan hasil analisis data yang telah diperoleh dari hasil penelitian yang akan diuraikan secara deskriptif dalam bentuk narasi. Pada hasil penelitian ini diharapkan dapat memberikan masukan untuk pelaksanaan Budaya 5S sebagai salah satu cara Reformasi Birokrasi dalam meningkat pelayanan publik di SMK SMAK Padang.

1. Pelaksanaan Reformasi Birokrasi di SMK SMAK Padang

Pelaksanan reformasi birokrasi di instansi SMK SMAK Padang mulai dilakukan sejak dikeluarkannya Peraturan Presiden Nomor 81 Tahun 2010 tentang Grand Design Reformasi Birokrasi yang mengatur pelaksanaan program tersebut dengan tiga sasaran, yaitu meliputi peningkatan kapasitas dan akuntabilitas organisasi, pemerintah yang bersih dan bebas KKN, serta meningkatkan pelayanan publik.

Sejalan dengan Road Map Kementerian Perindustrian Republik Indonesia, SMK SMAK Padang salah satu instansi vertikal dari Kementerian Perindustrian yang bertanggungjawab kepada Kepala Badan Pengembangan Sumber Daya Manusia Industri telah turut serta dalam pelaksanaan reformasi birokrasi. Bukti dan komitmen SMK SMAK Padang dalam mempercepat pelaksanaan reformasi birokrasi diantara telah melakukan beberapa program diantaranya, yaitu:

a. Pengendalian Gratifikasi

Upaya wujud pelaksanaan Zona Integritas di SMK SMAK Padang adalah peningkatan pencegahan terjadinya tindak pidana korupsi yaitu dengan pengendalian gratifikasi. Gratifikasi memiliki arti yang cukup luas, yakni meliputi pemberian uang/ barang/ dan fasilitas lainnya. Menurut pasal 12B ayat (1) UU No.31/1999 jo UU No. 20/2001, berbunyi "Setiap gratifikasi kepada pegawai negeri atau penyelenggara negara dianggap pemberian suap, apabila berhubungan dengan jabatannya dan berlawanan dengan kewajiban atau tugasnya".

Salah satu kebiasaan yang berlaku dan sudah dianggap menjadi hal wajar di masyarakat adalah pemberian tanda terima kasuh atas jasa yang telah diberikan oleh Petugas, baik dalam 
Kebijakan: Jurnal Ilmu Administrasi

Volume 12, Nomor 2, Juni 2021

E-ISSN: 2656-2820

P-ISSN 1829-5762

bentuk barang atau uang. Kebiasaan tersebut sudah pasti bersifat negatif yang mengarah dan berpotensi untuk melakukan perbuatan korupsi di kemudian hari. Sebagai antisipasi terjadinya hal tersebut, ada 3 cara SMK SMAK Padang mencegah godaan gratifikasi, yaitu (1) Memberikan edukasi tentang Gratifikasi pada seluruh pegawai dan seluruh peserta didik di lingkungan SMK SMAK Padang; (2) Meningkatkan kesadaran pegawai, peserta didik, orang tua dan masyarakat untuk melaporkan gratifikasi. Pada website resmi SMK SMAK Padang, terdapat laman untuk membuat pengaduan gratifikasi. Langkah untuk membuat pengaduan gratifikasi di SMK SMAK Padang dapat diakses dilink berikut: https://www.smksmakpa.sch.id/index.php/gratifikasi/fgratifikasi.

SMK SMAK Padang akan terus berupaya melakukan pengendalian gratifikasi sebagai wujud Zona Integritas (ZI) menuju Wilayah Bebas Korupsi (WBK) dan Wilayah Birokrasi Bersih Melayani (WBBM); (3) Meminimalkan psikologis para pelapor gratifikasi. Biasanya para pegawai SMK SMAK Padang enggan melaporkan gratifikasi yang diterima karena takut imbas di belakangnya. Maka, SMK SMAK Padang memiliki komitmen untuk menyembunyikan identitas para pelapor gratifikasi tersebut.
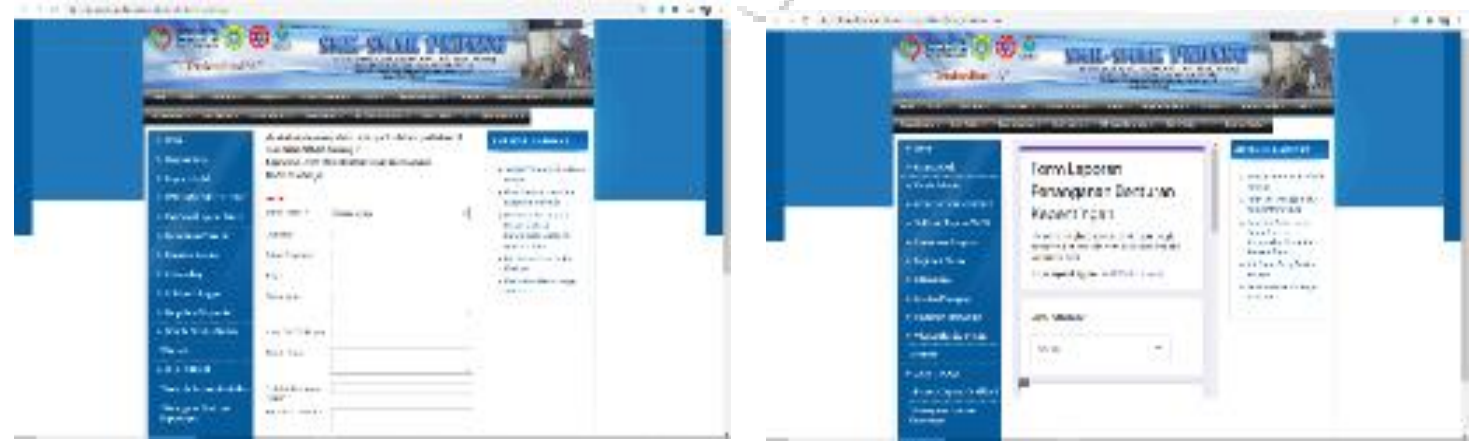

Gambar 1: Form Laporan Gratifikasi dan Form Laporan Benturan Kepentingan

b. Jarvis One Stop Integrated Service

Penerimaan Peserta Didik Baru di seluruh unit pendidikan milik Kemenperin BPSDMI Kementerian Perindustrian disebut dengan Jarvis. Jarvis ialah Jalur Penerimaan Vokasi Industri yang dilaksanakan secara online melalui portal www.jarvis.kemenperin.go.id. Program Jarvis ini diinisiasi untuk memudahkan calon peserta didik mendaftar pada sekolah di lingkungan Kementerian Perindustrian secara terpusat (one-stop integrated service) dan dilakukan secara serentak di seluruh Indonesia.
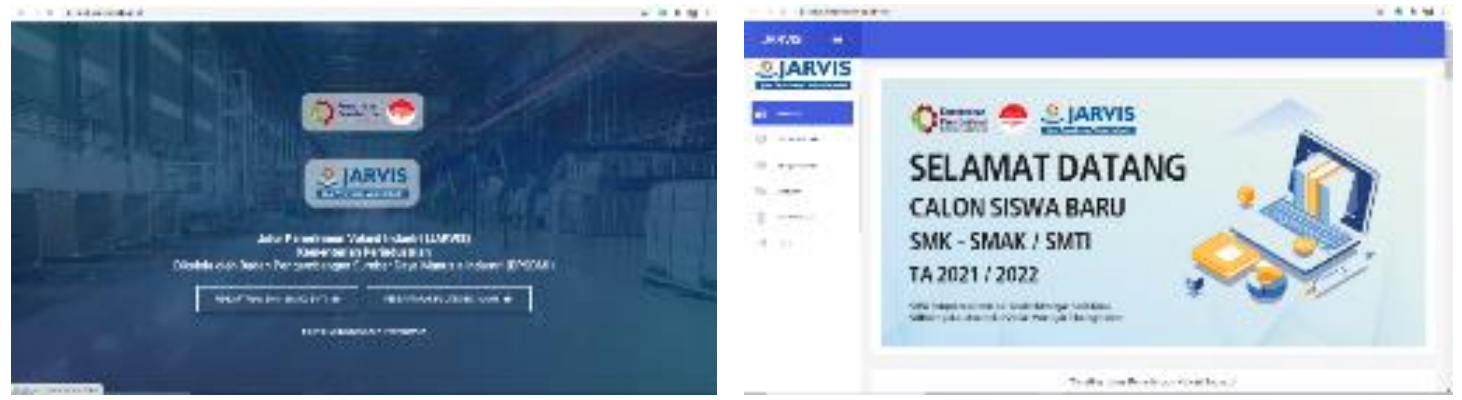

Gambar 2: Website Jarvis Kemenperin

c. Inovasi Pelayanan Publik

Internalisasi nilai-nilai Reformasi Birokrasi terus-menerus dilakukan oleh seluruh pegawai di lingkungan SMK SMAK Padang. Hal tersebut terlaksana dengan melakukan berbagai macam inovasi, salah satunya inovasi pada pelayanan publik. Menurut Peraturan Menteri PANRB Nomor 30 Tahun 2014, Inovasi Pelayanan Publik merupakan terobosan jenis pelayanan publik baik yang merupakan gagasan/ ide kreatif orisinal dan/atau adaptasi/ modifikasi yang memberikan manfaat bagi masyarakat secara langsung maupun tidak langsung. 
Kebijakan: Jurnal Ilmu Administrasi

Volume 12, Nomor 2, Juni 2021

E-ISSN: 2656-2820

P-ISSN 1829-5762

SMK-SMAK Padang tidak henti-hentinya berinovasi. Hal tersebut terbukti pada Kompetisi Inovasi Layanan Publik (SINOVIK) 2021, SMK-SMAK Padang terpilih menjadi 4 (empat) besar, bahkan Gubernur Sumatera Barat merekomendasikan pihak SMK SMAK Padang untuk bekerja sama dengan Dinas Peternakan dan Kesehatan Hewan Sumatera Barat guna pemanfaatan bahan baku darah ari Rumah Potong Hewan (Jawapos, 2021).

Dalam inovasi pelayanan publik, SMK SMAK Padang mendapat respons positif dari Pemprov Sumbar yang bertekad untuk menjadikan inovasi tersebut sebagai wujud pelayanan publik yang berdampak positif terhadap lingkungan. Inovasi itu pun menjadi unggulan untuk penilaian dalam kompetisi Sinovik 2021.
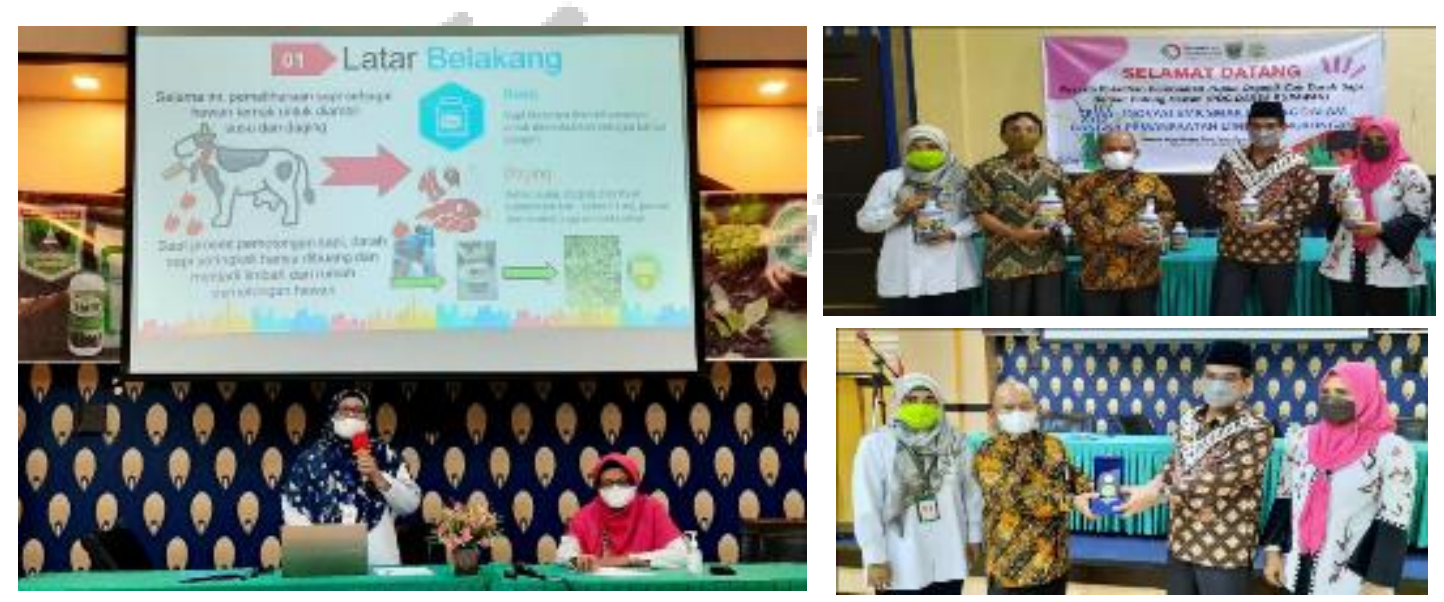

Gambar 3: Inovasi Layanan Publik SMK SMAK Padang Bekerjasama dengan Pemprov Sumbar

2. Peningkatan Kualitas Pelayanan Publik di SMK SMAK Padang

Pelayanan publik merupakan sikap yang ditampilkan atau ditunjukkan oleh aparatur layanan publik dalam melaksanakan tugasnya. Hakikat pelayanan publik dalam Keputusan MENPAN Nomor 63 Tahun 2004 menyatakan bahwa hakikat pelayanan publik adalah pemberian pelayanan prima kepada masyarakat yang merupakan perwujudan kewajiban aparatur pemerintah sebagai abdi masyarakat.

Peningkatan kualitas pelayanan publik erat kaiatannya dengan pembangunan Zona Integritas. Komitmen SMK SMAK Padang dalam Zona Integritas WBK dan WBBM telah dilaksanakan dengan baik, hal tersebut dilakukan dengan melakukan manajemen perubahan, membentuk Tim Pembangunan Zona Integritas, melakukan kegiatan yang relevan dengan tujuan pembangunan Zona Integritas.

Zona Integritas lekat dengan pelayanan yang optimal dan maksimal, salah satu upaya yang telah dilaksanakan SMK SMAK Padang yaitu dengan memberikan pelatihan secara konsisten bagaimana melayani masyarakat atau pelanggan sesuai standar. Standar Pelayanan Prosedur (SOP) yang diterpakan di lingkungan SMK SMAK Padang telah ditetapkan melalui Maklumat dan Motto Layanan Publik. Maklumat Layanan Publik yaitu "Dengan ini, kami menyatakan sanggup menyelenggarakan pelayanan sesuai standar pelayanan yang telah ditetapkan dan apabila tidak menepati janji ini, kami siap menerima sanksi sesuai dengan peraturan perundang-undangan". Sedangkan Motto Pelayanan Publik yaitu "Melayani dengan Senyum, Cepat, Tepat, Mudah dan Berkualitas".
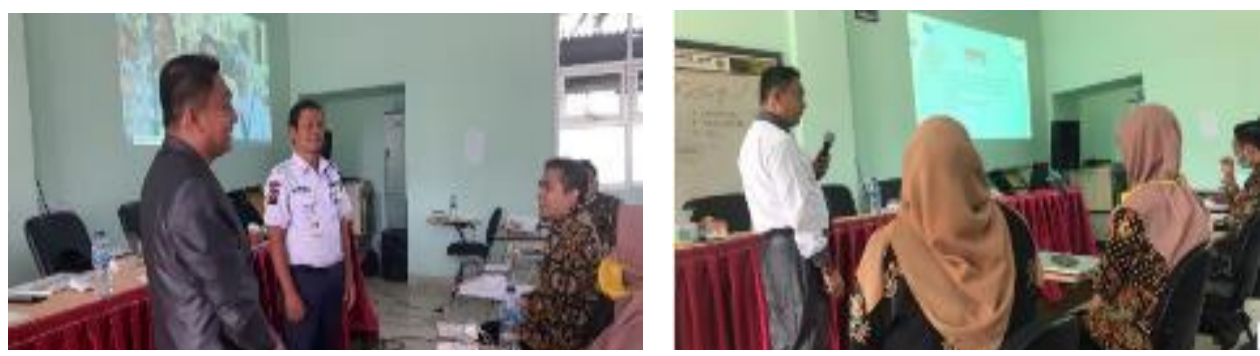

Gambar 4: Pelatihan Pelayanan Publik SMK SMAK Padang 
Sesuai dengan Motto Layanan Publik, melaksanakan Budaya 5S adalah suatu keharusan. Budaya 5S telah memberikan dampak yang besar dalam pelayanan di lingkungan SMK SMAK Padang, sehingga apabila dilaksanakan secara terus-menerus maka akan membentuk suatu kebiasaan.

Dari hasil temuan peneliti di lapangan, peneliti menemukan bahwa pelaksanaan peningkatan pelayanan publik di SMK SMAK Padang dalam rangkaian program Zona Integritas WBK-WBBM sudah baik. SMK SMAK Padang menjadi tempat untuk menyoalisasikan nilai-nilai budaya yang tidak hanya terbatas hanya nilai-nilai keilmuan saja, namun semua nilai-nilai kehidupan yang memungkinkan bisa mewujudkan manusia yang berbudi dan berbudaya. Budaya sekolah berperan dalam perbaikan mutu sekolah, maka dari itu sekolah harus memahami budayanya sebelum melakukan perbaikan mutu sekolah (Sofyan, 2005:5).

Melaksanakan Reformasi Birokrasi telah lama dilakukan di lingkungan SMK SMAK Padang, yang merupakan salah satu upaya dari instansi untuk mewujudkan Nawacita Presiden saat itu, yaitu Membuat Pemerintah selalu hadir dengan membangun tata kelola pemerintahan yang bersih, efektif, demokratis dan terpercaya, sedangkan membudayakan 5S (Senyum, Salam, Sapa, Sopan, Santun) yang merupakan wujud Nawacita poin kedelapan yaitu Melakukan revolusi karakter bangsa.

Menerapkan Budaya 5S merupakan wujud interaksi sosial antara seluruh pegawai SMK SMAK Padang dengan para siswa-siswi maupun interaksi dengan tamu dan masyarakat dalam kegiatan akademik atau non-akademik. Penerapan Budaya 5S telah menciptakan lingkungan kerja yang nyaman, aman, kondusif dan menyenangkan sehingga dapat membentuk para pegawai yang disiplin didalam memberikan pelayanan kepada masyarakat. SMK SMAK Padang merupakan satker yang berpredikat Wilayah Birokrasi Bersih dan Melayani (WBBM) yang telah memenuhi sebagian besar program Manajemen Perubahan, Penataan Tatalaksana, Penataan Sistem Manajemen SDM, Penguatan Pengawasan, Penguatan Akuntabilitas Kinerja dan Penguatan Kualitas Pelayanan Publik. Maka dari itu SMK SMAK Padang akan terus memberikan pelayanan yang cepat, tepat, ramah, transaparan dan adil supaya peserta didik dan masyarakat puas dengan pelayanan yang diberikan.

1. Pelayanan dengan $5 \mathrm{~S}$

Motto layanan publik di SMK SMAK Padang yaitu Melayani dengan Senyum, maka seluruh pegawai dituntut memiliki sikap ramah-tamah dalam menghadapi tamu atau masyarakat. Sikap ramah-tamah dan sopan-santun tersebut diwujudkan dalam pelayanan yang diberikan seperti menyapa masyarakat yang berkunjung (salam), berdialog dan bertanya tentang kepentingan dan keperluannya ketika berkunjung, serta peduli terhadap aspirasi masyarakat yang dapat dijadikan sebagai acuan dalam perumusan dan pelaksanaan pelayanan, karena aspirasi masyarakat merupakan masukan, saran, pendapat dan ide-ide yang dapat dijadikan sebagai bahan evaluasi meningkatkan pelayanan prima serta meningkatkan kapasitas dan akuntabilitas kinerja.

2. Pelayanan Cepat dan Tepat

Birokrasi yang lama dan selalu berbelit-belit serta kurang efisien dinilai kurang efektif diterapkan pada saat ini. Dengan adanya reformasi birokrasi, konsep pelayanan di SMK SMAK Padang banyak melakukan pembenahan. Evaluasi konsep pelayanan pun dilakukan dengan memberikan pelayanan yang berorientasi pada masyarakat secara cepat dan tepat. Kecepatan pegawai SMK SMAK Padang dapat dilihat bagaimana pegawai tersebut merespon tamu dan masyarakat, yaitu dengan memberi pelayanan disaat itu juga dan tidak menunda-nunda waktu.
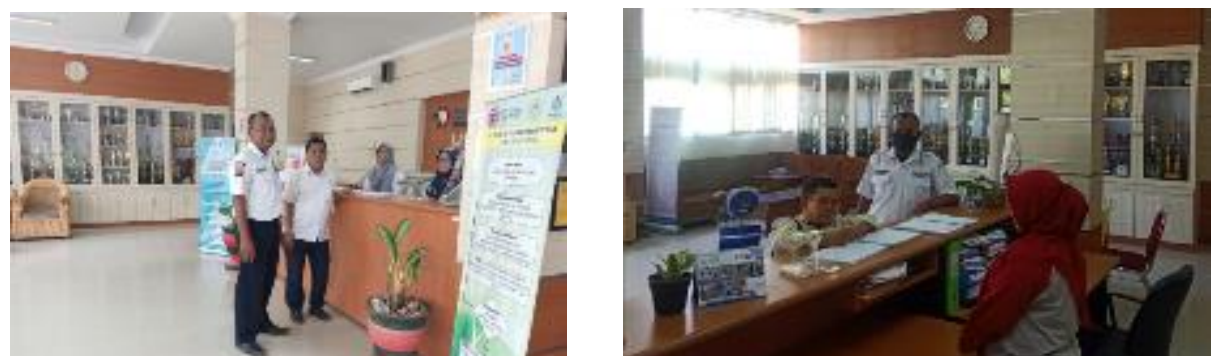

Gambar 5: Pelayanan Tamu dan Masyarakat di SMK SMAK Padang 
3. Pelayanan Transparan

Komitmen SMK SMAK Padang dalam Zona Integritas WBK WBBM diwujudkan dengan memberikan pelayanan maksimal kepada tamu atau masyarakat yaitu transparan tanpa biaya-biaya administrasi dan juga menolak keras untuk tidak menerima sumbangan dalam bentuk apapun. Segala aspek penyelenggaraan pelayanan di SMK SMAK Padang seperti persyaratan pendaftaran peserta didik, rincian biaya sekolah, cara pelayanan, cara pelaporan serta pengguna layanan dipublikasikan secara terbuka sehingga mudah diakses dan dipahami oleh masyarakat.

Dari hasil temuan penulis di lapangan, penulis menemukan bahwa reformasi birokrasi yang sedang dan telah dilaksanakan di SMK SMAK Padang dalam rangka komitmen Zona Integritas WBK WBBM sudah sangat baik. Namun, penulis masih memerlukan sumber lain diluar instansi untuk memperkuat hasil temuan sebelumnya, yaitu keberhasilan SMK SMAK Padang dalam memperoleh predikat Wilayah Birokrasi Bersih Melayani (WBBM) di lingkungan satker Kementerian Perindustrian tidak lepas dari peran dan ketegasan dan inisiatif seorang pemimpin. Peran pemimpin dalam pembenahan Budaya Kerja di SMK SMAK Padang menjadi awal yang baik untuk pembenahan di sektor pelayanan publik. Ketegasan pemimpin sangat diperlukan dalam memperbaiki kualitas pelayanan publik SMK SMAK Padang, sebab layanan publik merupakan garda terdepan dalam memberikan pelayanan kepada masyarakat. Maka dari itu, SMK SMAK Padang meningkatkan fasilitas untuk memudahkan pelayanan kepada masyarakat. Fasilitas layanan publik tersebut seperti petugas yang ramah dan selalu stand-by pada jam kerja, loket antrian, secara on, ruang tunggu yang nyaman, serta adanya weekend service dan layanan aduan 24 jam yang bisa diakses secara online.

\section{SIMPULAN}

Pelaksanaan reformasi birokrasi di SMK SMAK Padang sudah berjalan dengan sangat baik. Penerapan Budaya 5S dan penggunaan teknologi diaplikasikan secara maksimal dalam layanan publik, hal itu tampak pada proses birokrasi di SMK SMAK Padang semakin cepat dan ringkas. Disisi lain, para pegawai telah melaksanakan SOP Pelayanan Publik sesuai dengan prosedur. Selain itu juga didukung karena adanya komitmen dengan ditanda tangani Pakta Integritas oleh setiap pegawai untuk berperan aktif dalam mewujudkan Wilayah Bebas dari Korupsi (WBK) / Wilayah Birokrasi Bersih dan Melayani (WBBM) di lingkungan SMK SMAK Padang. Para pegawai SMK SMAK Padang juga melakukan gerakan reformasi birokrasi utamanya dengan melakukan berbagai macam inovasi sebagai wujud melayani masyarakat secara optimal.

\section{DAFTAR PUSTAKA}

Hariandja, Denny, B.C, (1999), Birokrasi Nan Pongah, Belajar dari Kegagalan Orde Baru. Jakarta: Kanisius.

Jawapos. (2021). Gubernur Sumbar Dukung Pengembangan Pupuk Darah Sapi SMAK Padang.

Diunduh di https://padek.jawapos.com/gubernur-sumbar-dukung-pengembangan-pupukdarah-sapi-smak-padang/

Kemenpan RI. (2020). Penghargaan bagi Unit Kerja Peraih WBK WBBM. Diunduh dari https://www.menpan.go.id/site/berita-terkini/menteri-tjahjo-akan-berikan-penghargaan-bagiunit-kerja-peraih-wbk-wbbm

Keputusan Menteri Pendayagunaan Aparatur Negara Nomor 63 Tahun 2004 tentang Pedoman Umum Penyelenggaraan Pelayanan Publik

Kominfo RI. (2016). Joko Widodo, Reformasi Birokrasi, Pelayanan Terbaik Untuk Republik. Diunduh dari https://www.kominfo.go.id/content/detail/8228/reformasi-birokrasi-pelayanan-terbaikuntuk-republik/0/kerja_nyata

Lubis, Mochtar dan Scoot, J. C. (1987). Mafia dan Korupsi Birokrasi. Jakarta: Yayasan Obor Indonesia. 
Kebijakan: Jurnal Ilmu Administrasi

Volume 12, Nomor 2, Juni 2021

E-ISSN: 2656-2820

P-ISSN 1829-5762

Moenir, H.A.S. (2001). Manajemen Pelayanan Umum di Indonesia. Jakarta: Bumi Aksara.

Peraturan Menteri PANRB Nomor 30 Tahun 2014 tentang Inovasi Pelayanan Publik

Peraturan Presiden Nomor 81 Tahun 2010 tentang Grand Design Reformasi Birokrasi

Radio Republik Indonesia. (2021). Pupuk Organik Cari SMK SMAK Padang Masuk Nominasi Inovasi Kemenperin. Diunduh di https://rri.co.id/padang/1228-pendidikan/997113/pupuk-organik-cairsmk-smak-padang-masuk-nominasi-inovasi-

kemenperinri?utm_source=terbaru_widget\&utm_medium=internal_link\&utm_campaign=Ge neral\%20Campaign

Rohman, Arif. (2012). Kebijakan Pendidikan: Analisis Dinamika Formulasi dan Implementasi. Yogyakarta: Aswaja Pressindo.

Sedarmayanti. (2009). Reformasi Administrasi Publik, Reformasi Birokrasi, dan Kepemimpinan Masa Depan : Mewujudkan Pelayanan Prima dan Kepemerintahan yang Baik. Bandung: Refika Aditama.

Sofyan, Herminarto. (2005). Pengembangan Kultur Sekolah. Yogyakarta: Program Pascasarjana Universitas Negeri Yogyakarta

Undang-Undang Republik Indonesia Nomor 20 Tahun 2001 Tentang Perubahan Atas Undang-Undang Nomor 31 Tahun 1999 Tentang Pemberantasan Tindak Pidana Korupsi 